Volume 18 Number 2 December 2018. p.301-316 https://doi.org/10.30603/au.v18i2.551

\title{
Sistem Pengajian Kitab Kuning pada Mahasiswa di Perguruan Tinggi
}

\author{
Mujizatullah
}

Balai Penelitian dan Pengembangan Agama Makassar

\begin{abstract}
This article explains the uniqueness of the educational system of Ma'had Al-Birr of the University of Muhammadiyah Makassar which is studying Kitab Kuning ( a special book for Islamic boarding school). the studying of Kitab Kuning is rarely found at college level. However, the studying of Kitab Kuning is an essential tradition to keep the existence of Islamic institution. It becomes the tool to create young Islamic parsons. Through the good implementation of learning method and strategy, a hundreds of students have been graduated from Ma'had Al-Birr of the University of Muhammadiyah Makassar. their good understanding of Kitab Kuning, they will be an agent of change of Islam society. the studying of KItab Kuning at Ma'had Al-Birr of the University of Muhammadiyah Makassar became the answer of society need of young Islamic parsons who have good skill in speaking Arabic language and also have good understanding of Kitab Kuning.
\end{abstract}

\section{Abstrak}

Artikel ini menjelaskan keunikan lembaga pendidikan Ma'had Al-Birr Universitas Muhammadiyah Makassar yang memiliki sistem pengajian kitab kuning. Pengajian kitab kuning sangat jarang ditemukan di Perguruan tinggi. Pengajian kitab kuning merupakan tradisi penting dari keberadaan suatu lembaga pendidikan Islam. Pengajian kitab kuning adalah salah satu model pembinaan kader-kader ulama muda. Melalui metode dan strategi pembelajaran yang baik, ratusan alumni telah lahir dari 'rahim' Ma'had Al-Birr Universitas Muhammadiyah Makassar. Dengan pemahaman dan penguasaan kitab kuning yang memadai mereka akan menjadi muballig yang mencerahkan (agent of change) di tengah-tengah umat. Pengajian kitab kuning pada mahasiswa di Ma'had Al-Birr dapat menjadi jawaban atas kebutuhan umat Islam terhadap sosok panutan di tengah kelangkaan ulama yang cakap berkomunikasi dalam bahasa Arab sekaligus memiliki pemahaman kitab kuning yang baik.

\section{Kata Kunci; Pengajian, Kitab Kuning, Ulama, Ma'had Al-Birr}

Author correspondence

Email: mukjizatlitbang@gmail.com

Available online at http://journal.iaingorontalo.ac.id/index.php/au/index 


\section{A. Pendahuluan}

Pendidikan agama merupakan upaya sadar untuk mentaati ketentuan Allah sebagai guidance (pedoman) dan dasar para peserta didik agar berpengetahuan keagamaan dan handal dalam menjalankan ketentuan-ketentuan Allah secara keseluruhan. Melalui pendidikan agama dapat dicapai kesatuan moralitas dan rasionalitas, sehingga tujuan pendidikan nasional dan pendidikan Islam dapat dicapai sekaligus secara bersamaan. Sebagaimana tertuang dalam Undang-Undang RI No. 20/2003 Bab II Pasal 2, tentang Tujuan Pendidikan Nasional bahwa:

"Pendidikan nasional bertujuan untuk berkembangnya potensi peserta didik agar menjadi manusia yang beriman dan bertakwa kepada Tuhan Yang Maha Esa, berakhlak mulia, sehat, berilmu, cakap, mandiri, kreatif, dan menjadi warga yang demokratis serta bertanggung jawab"

Guna mencapai tujuan dimaksud, lembaga pendidikan Islam membuat konsep pendidikan secara holistik dan komprehensif melalui penggalian khasanah kitab-kitab klasik Islam, sekaligus mengembangkan kemandirian berfikir untuk mengaplikasikan ilmu pengetahuan setelah mereka keluar dari perguruan tinggi tersebut. 1 Dengan demikian lembaga pendidikan Islam nantinya akan mampu menghasilkan luaran dengan jaminan kualitas yang memadai, mampu menginternalisasikan, mengaktualisasikan, dan mengimplementasikan ilmunya dalam berbagai bidang di tengah-tengah masyarakat.

Pengajian kitab kuning merupakan salahsatu bentuk pendidikan Islam yang sudah ada sejak masa-masa awal Islam. ${ }^{2}$ Maka tak salah jika dikatakan bahwa model pendidikan berupa pengajian kitab adalah sistem pendidikan salaf atau tradisional yang berangkat dari pola pembelajaran yang sangat sederhana, dengan hanya melibatkan guru (kiyai), murid dan kitab sebagai sumber belajarnya, umumnya kegiatan pengajian dilakukan di masjid atau pondok pesantren. Menurut Mastuhu (1994) Kegiatan belajar seperti ini dikatakan sebagai mengaji secara kolektif.

\footnotetext{
${ }^{1}$ Rahim, Kendali Mutu Pendidikan Agama Islam (Jakarta: Departemen Agarna RI, 2001), 10.

2 Marzuki Wahid, Pesantren Masa Depan: Wacana Pemberdayaan Dan Transformasi Pesantren (Jakarta: Pustaka Hidayah, 1999), 34.
} 
Pengajian kitab sebagai tradisi merupakan salah satu unsur yang terpenting dari keberadaan suatu lembaga pendidikan Islam. Penggalian khasanah budaya Islam melalui pengakian kitab inilah yang membedakannya dengan lembaga pendidikan lainnya. ${ }^{3}$ Ma'had sebagai lembaga pendidikan Islam tidak dapat diragukan lagi memiliki peran sebagai pusat transmisi dan desiminasi ilmu-ilmu keislaman, terutama yang bersifat kajian-kajian klasik.

Penyusunan kitab oleh ulama-ulama zaman dahulu merupakan salahsatu tradisi keilmuan Islam, karena hampir pada tiap-tiap masalah terdapat lebih dari satu pendapat atau pendekatan berbeda dalam tradisi keilmuan Islam. Berbagai jenis kitab dilahirkan dari tangan-tangan ulama Islam sejak dahulu, bukan hanya jenisnya yang beragam tetapi latar belakang dan pendekatan yang dipakai juga sangat bervariasi, dari satu ulama ke ulama lain bahkan dari satu ke periode yang lain.

Persoalannya adalah, dewasa ini ulama yang betul-betul memiliki penguasaan terhadap kutub turās (kitab klasik) semakin berkurang sementara masalah umat malah kian bertambah. Sehingga kebutuhan umat sangat besar terhadap lahirnya ulama-ulama yang memiliki kepakaran dalam berbagai bidang ilmu syariat. Menurut Quraish Shihab bahwa, ulama adalah mereka yang bertakwa, berbudi luhur, memahami dan menguasai berbagai bidang ilmu pengetahuan, dan mampu mentransformasikannya serta mengimplementasikannya dalam kehidupan sehari-hari. ${ }^{4}$

Kitab merupakan istilah khusus yang digunakan untuk menyebut karya tulis di bidang keagamaan yang ditulis dengan bahasa Arab oleh para ulama pada abad pertengahan. Sebutan ini yang membedakan dengan karya tulis pada umumnya yang ditulis dengan huruf selain Arab, yang dinamakan buku. Ruang lingkup kajian materinya cukup beragam, mulai dari tafsir, fiqh, aqidah, akhlak, hadits, hingga pada ilmu-ilmu sosial dan kemasyarakatan. Biasanya kitab yang dijadikan rujukan belajar di lembaga pendidikan Islam, baik

\footnotetext{
3 Zamakhsyari Dhofier, The Pesantren Tradition: The Role of the Kyai in the Maintenance of Traditional Islam in Java (Tempe, Ariz.: Monograph Series Press, Program for Southeast Asian Studies, Arizona State University, 1999), 66.

${ }^{4}$ Atik Wartini, “Corak Penafsiran M. Quraish Shihab Dalam Tafsir Al-Misbah," Hunafa: Jurnal Studia Islamika 11, no. 1 (2014): 110.
} 
modern maupun tradisional seperti ma'had atau pondok pesantren, dinamakan kitab kuning atau kitab gundul (tidak berharakat). ${ }^{5}$

Dalam tradisi intelektual Islam, khususnya di Timur Tengah, dikenal dua istilah untuk menyebut kategori karya-karya ilmiah yaitu: kategori pertama disebut kitab-kitab klasik (al-kutub al-qadimah); kategori kedua disebut kitabkitab modern (al-kutub al-asriyyah). Perbedaan yang pertama dari yang kedua dicirikan antara lain oleh cara penulisannya yang tidak mengenal pemberhentian, tanda baca (punctuation), dan kesan bahasanya yang berat, klasik, dan tanpa tanda syakl/harakat. Penyebutan kitab kuning pada dasarnya mengacu pada kategori yang pertama, yakni kitab-kitab klasik (al-kutub al-qadimah. ${ }^{6}$

Namun demikian, ciri semacam ini mulai hilang dengan diterbitkannya kitab-kitab serupa dengan format dan lay out yang lebih elegan, dengan dicetak di atas kertas putih sebagai bahan materialnya, dan sebagian besar telah dijilid rapi secara lux. Tampilan kitab kuning sekarang yang seperti ini relatif menghilangkan kesan klasiknya. Dengan demikian penampilan fisiknya sulit dibedakan antara kitab-kitab baru (al-kutub al-asriyyah) dan kitab-kitab klasik (al-kutub alqadimah).

Namun bukan di sini persoalannya, karena secara substansial tidak ada perubahan yang berarti dalam penulisannya yang masih tetap tidak ber-harakat, karena wujudnya yang tidak ber-harakat inilah pembaca dituntut untuk memiliki kemampuan keilmuan yang maksimal, khususnya dalam bahasa Arab. Setidaknya pembaca harus menguasai disiplin ilmu Nahwu dan Sharaf di samping penguasaan kosakata bahasa Arab yang banyak. Karena semua kitab tersebut disusun dalam bahasa Arab sehingga kemampuan mendalami dan menguasai kaedah-kaedah bahasa Arab merupakan hal penting untuk dapat membaca dan memahami kitabkitab tersebut.

Sedangkan mengenai penyebutan istilah sebagai Kitab kuning, dikarenakan memang kitab-kitab tersebut kertasnya berwarna kuning, hal ini disebabkan warna kuning dianggap lebih nyaman dan mudah dibaca dalam keadaan yang

\footnotetext{
${ }^{5}$ Azyumardi Azra, Pendidikan Islam : tradisi dan modernisasi menuju milenium baru (Jakarta: Logos Wacana Ilmu, 2002), 78.

${ }^{6}$ Wahid, Pesantren Masa Depan: Wacana Pemberdayaan Dan Transformasi Pesantren, 77.
} 
redup. Ketika penerangan masih terbatas pada masa lampau, utamanya di desadesa, para santri terbiasa belajar di malam hari dengan pencahayaan seadanya.

Sebab lainnya, adalah karena umur kertas yang telah kuno yang turut membuat kertas semakin lama akan menguning dan menjadi lebih gelap secara alami. Menurut Affandi Mochtar, ${ }^{7}$ Karena warna kertasnya berwarna kuning, akhirnya untuk memudahkan penyebutan kitab tersebut, maka dikatakan "Kitab Kuning"

Ma'had Al-Birr Universitas Muammadiyah Makassar merupakan sebuah lembaga pendidikan Islam yang bergerak di bidang pengajaran bahasa Arab dan ilmu-ilmu keislaman. Ma'had Al-Birr didirikan pada tahun 1996 sebagai wujud kerjasama antara Pimpinan Pusat Muhammadiyah dengan Yayasan Muslim Asia, Jakarta. Lembaga ini menempati areal di dalam kampus Universitas Muhammadiyah (Unismuh) Makassar bertujuan menghasilkan alumni muslim yang berkompeten dalam ilmu Islam, terampil menerjemahkan dan berkomunikasi dalam bahasa Arab, ahli dalam menyebarkan nilai-nilai keislaman dan bahasa Arab, serta mampu menjawab masalah-masalah keagamaan yang berkembang di tengah masyarakat.

Pendirian Ma'had Al-Birr Unismuh merupakan salahsatu 'jawaban' dari Persyarikatan Muhammadiyah terhadap tingginya harapan masyarakat, khususnya warga Muhammadiyah, akan lahirnya kader-kader ulama muda persyarikatan yang mempunyai kemampuan berkomunikasi dalam bahasa Arab tetapi juga ahli dalam al-'ulūm al-syar'iyah (ilmu-ilmu syari'at). Untuk mencapai tujuan tersebut, maka salah satu kegiatan yang dilakukan secara rutin di Ma'had Al-Birr adalah Pengajian Kitab Kuning yang wajib diikuti oleh semua mahasiswa dari semua tingkatan.

Penelitian ini menerapkan jenis penelitian kualitatif deskriptif. Menurut Sugiyono, metode penelitian kualitatif adalah metode penelitian yang digunakan untuk meneliti pada kondisi objek yang alamiah (natural setting) dimana posisi peneliti sebagai instrumen kunci. ${ }^{8}$ Penelitian kualitatif adalah penelitian yang

\footnotetext{
7 Wahid, 78.

${ }^{8}$ Ahmad Kadir, Dasar-Dasar Metodologi Penelitian Kualitatif (Makassar: CV. Indobis Media Centre, 20013), 43.
} 
bertujuan untuk memahami fenomena tentang apa yang dialami oleh subjek penelitian, misalnya perilaku, persepsi, motivasi, tindakan dan lain-lain, secara holistik, dan dengan cara deskripsi dalam bentuk kata-kata dan bahasa pada suatu konteks khusus yang alamiah dan dengan memanfaatkan berbagai metode ilmiah. ${ }^{9}$

Penelitian kualitatif deskriptif yang peneliti maksud adalah penelitian untuk menghasilkan informasi yang deskriptif yang berupa gambaran sistematis, cermat, mendalam, dan menyeluruh terhadap sistem pengajian kitab yang dilaksanakan di Ma'had Al-Birr serta untuk mengungkap bagaimana gambaran perilaku mahasiswa dalam mengimplementasikan pembelajaran kitab. Serta peranan metode sorogan dan bandongan dalam peningkatan pemahaman teks kitab-kitab klasik mahasiswa Ma'had Al-Birr Unismuh Makassar.

Selain itu, untuk dapat menggambarkan faktor-faktor pendukung dan penghambat sistem pengajian kitab kuning dan upaya-upaya optimalisasi peranan metode sorogan dan bandongan dalam meningkatan kemampuan pemahaman teks kitab-kitab klasik para mahasiswanya yang dilakukan oleh pihak Ma'had AlBirr Unismuh Makassar.

Pendekatan-pendekatan dimaksud dapat dijelaskan sebagai berikut:

a. Pendekatan Teologis

Pendekatan ini adalah pendekatan yang beranjak dari konsep-konsep dan teori-teori teologi, yang terdapat dalam Al-Qur'an maupun hadits .10 Selain itu, data-data yang diperoleh dari sumber-sumber rujukan dan hasil penelitian akan dianalisis dengan menggunakan pendekatan teologis ini yang bertujuan menemukan keterkaitan data tersebut dengan konsep pendidikan yang ada. Dalam hal ini penulis mencoba mengungkapkan sistem pengajian kitab kuning pada mahasiswa Ma'had Al-Birr Unismuh Makassar.

Metode pengajian yang mengarah pada nilai spiritual inilah yang menyebabkan penulis mutlak menggunakan pendekatan teologis normative. Pendekatan teologis normatif digunakan dalam rangka melihat fenomenafenomena keagamaan dan pelaksanaan ajaran agama itu sendiri. Pendekatan ini

\footnotetext{
${ }^{9}$ S.J Moleong, Metodologi Penelitian Kualitatif (Bandung: Remaja Rosdakarya, 1991), 57.

10 Amin Abdullah, Pengembangan Metode Studi Islam Dalam Perspektif Hermeneutika Sosial dan Budaya, vol. 6, 2003, 6.
} 
mutlak digunakan sebagai cara pandang dalam penelitian agama untuk mengetahui secara normative dan menjunjung tinggi nilai-nilai luhur.

b. Pendekatan Sosiologis

Pendekatan ini dimaksudkan untuk menganalisa dan menggambarkan aspek-aspek sosial para mahasiswa sebagai satu komunitas dalam pembelajaran kitab kuning, baik berkaitan dengan interaksi mereka dengan sesama mahasiswa maupun dengan para pengajar mereka, dalam hal ini ustadz pengasu pengajian. Selain itu, keberadaan pelaksanaan pengajian kitab kuning di Ma'had Al-Birr Unismuh juga menjadi bagian penting bagi masyarakat sekitarnya, karena kegiatan pengajian tersebut pada dasarnya bersifat terbuka.

\section{c. Pendekatan Psikologis}

Pendekatan psikologis yang dimaksud dalam hal ini adalah menganalisis data dan memberikan interpretasi-interpretasi psikologis terhadap variabelvariabel data hasil penelitian, yaitu dengan mempelajari perilaku dan motivasi belajar mahasiswa Ma'had Al-Birr melalui gejala perilaku yang dapat diamati dan intensitas mereka dalam pengajian kitab kuning serta memperhatikan kemampuan penguasaan mereka terhadap teks-teks kitab klasik selama proses pengajian kitab kuning.

\section{d. Pendekatan Historis}

Pendekatan ini dipergunakan untuk melakukan penelusuran tentang sejarah keberadaan Ma'had Al-Birr Unismuh Makassar dan perkembangan kelembagaannya. Ma'had Al-Birr sejak awal pendiriannya sudah berada di dalam lingkungan Universitas Muhammadiyah Makassar, padahal dalam konsep pembinaan mahasiswanya memiliki kurikulum tersendiri yang justru mengacu kepada kurikulum lembaga bahasa Arab LIPIA Jakarta.

Dalam penelitian ini, informan yang terlibat secara langsung dengan proses wawancara mendalam sebanyak 5 (lima) orang pembina pada Ma'had Al-Birr Unismuh, yaitu sebagai berikut: 


\begin{tabular}{|l|l|l|}
\hline No & Nama Pembina/Ustadz & Kitab kuning yang diajarkan \\
\hline 1 & H. Lukman A. Shamad, Lc & Al-Rahiq al-Makhtum \\
\hline 2 & Dr. Abbas B Miro, Lc., MA & Subul al-Salam \\
\hline 3 & Syamsuddin, Lc & Fiqih al-Sunnah \\
\hline 4 & Muzakkir Ahlisan, Lc & Qawa'id al-Lugah \\
\hline 5 & La Sahidin, Lc & Al-Arba'in Al-Nawawiyah \\
\hline
\end{tabular}

Data yang diperoleh dalam penelitian ini dianalisis secara kualitatif, Penelitian ini merupakan penelitian kualitatif, dimana peneliti menjadi bagian dari key instrument, dilakukan dalam bentuk studi kasus. Proses pengolahannya mengikuti teori Miles dan Huberman ,bahwa proses pengolahan data melalui tiga tahap, yaitu: reduksi data, penyajian data (data display), dan verifikasi/penarikan kesimpulan. ${ }^{11}$

Peneliti mencoba memperoleh gambaran jelas tentang pengajian kitab kuning di Ma'had Al-Birr Universitas Muhammadiyah Makassar dengan tetap memperhatikan kualifikasi dan kompetensi. Prosedur penelitian dilakukan dengan cara interpretasi terhadap deskriptif studi lapangan berupa perilaku para ustadz yang mengajar di Ma'had baik yang tertulis, terucap maupun tingkah laku mereka dalam menyampaikan pengajian kitab kuning di Ma'had.

\section{B. Sistem Pengajian Kitab Kuning pada Mahasiswa}

Sistem adalah seperangkat komponen yang terkait, saling mempengaruhi dan beroperasi untuk mencapai tujuan tertentu. Dalam konteks upaya pemecahan masalah dan pencapaian tujuan, maka langkah-langkah itu harus berangkat atau dimulai dari konteks, input, proses, output dan berakhir dengan outcome (Hamzah, 2011). Mengacu pendapat di atas maka input, proses, output dalam pengajian kitab kuning pada mahasiswa di Ma'had Al-Birr Unismuh dapat dijelaskan sebagai berikut:

\footnotetext{
${ }^{11}$ Sugiyono, Metode Penelitian Kuantitatif Kualitatif Dan R\&D (Bandung: Alfabeta, 2008), 58.
} 


\section{Input pada Pengajian Kitab Kuning di Ma'had Al-Birr}

Input adalah bahan mentah yang dimasukkan ke dalam transformasi. Input pendidikan adalah segala sesuatu yang harus ada dan tersedia karena dibutuhkan untuk berlangsungnya suatu proses. Segala sesuatu yang dimaksud adalah berupa input sumberdaya, perangkat-perangkat lunak serta harapan-harapan sebagai alat dan pemandu bagi berlangsungnya sebuah proses. ${ }^{12}$

Adapun input pada pengajian kitab kuning pada mahasiswa di Ma'had AlBirr Unismuh adalah sebagai berikut:

a. Input Sumberdaya

Input sumberdaya pada pengajian kitab kuning di Ma'had Al-Birr Unismuh meliputi para mahasiswa dan mahasiswi yang terdiri dari empat tingkat/level pendidikan serta para ustadz pengasuh pengajian. Dalam pelaksanaan kegiatan pengajian kitab kuning pada mahasiswa di Ma'had Al-Birr Unismuh, mahasiswa merupakan elemen penting yang menjadikan kegiatan tersebut berlangsung dengan baik dan lancar. Mereka sangat termotivasi untuk selalu hadir pada pengajian kitab kuning. Bukan sekedar hadir untuk mendengarkan materi pengajian, tetapi mereka aktif mencatat hal-hal penting dan mempertanyakan sesuatu yang belum mereka pahami dari penjelasan ustadz.

Input sumberdaya lainnya adalah para pengasuh pengajian kitab kuning di Ma'had Al-Birr Unismuh. Mereka adalah para ustadz yang memiliki keahlian bahasa Arab yang sangat baik. Mereka semuanya bahkan sehari-hari juga adalah para pengajar bahasa Arab di kelas Ma'had Al-Birr Unismuh, sehingga dalam menyampaikan materi pengajian kitab kuning tentu tidak mengalami kendala yang berarti. Hal ini ditunjang oleh kemampuan penguasaan bahasa Arab para dosen di Ma'had Al-Birr. Modal penguasaan bahasa Arab yang baik inilah yang sangat mendukung terlaksananya kegiatan pengajian kitab kuning di Ma'had Al-Birr Unismuh Makassar.

b. Input Perangkat Lunak

Perangkat lunak dimaksud yaitu yang meliputi: peraturan-peraturan, deskripsi tugas, kurikulum, materi dan lain-lain. Dalam hal ini, Ma'had Al-Birr

\footnotetext{
${ }^{12}$ Suharsimi Arikunto, Manajemen Penelitian (Jakarta: Rineka Cipta, 2013), 73.
} 
Unismuh telah menetapkan kegiatan pengajian kitab kuning sebagai program Nasyath (ekstrakurikuler) utama sehingga ada aturan atau tata tertib yang mengikat setiap mahasiswa.

Tata tertib tersebut antara lain bahwa pengajian kitab kuning di masjid, adalah bersifat wajib untuk diikuti oleh semua mahasiswa di semua tingkatan di Ma'had Al-Birr Unismuh. Bagi yang tercatat tidak hadir mengikuti tanpa alasan yang jelas, maka akan dicatat oleh ketua tingkat untuk dilaporkan ke penanggung jawab kegiatan ekstrakurikuler. Untuk memantau kehadiran mahasiswa di pengajian kitab kuning, pihak penanggung jawab kegiatan memberlakukan sistem absensi yang dilakukan oleh masing-masing ketua kelas atau tingkat. Cara ini cukup efektif untuk membuat mahasiswa mau datang menghadiri pengajian kitab kuning di masjid.

Input perangkat lunak lainnya adalah isi atau materi pembelajaran. Input ini merupakan komponen penting dalam sistem pembelajaran. Materi pelajaran adalah substansi yang akan disampaikan dalam proses belajar mengajar. Tanpa bahan pelajaran proses belajar mengajar tidak akan berjalan. Karena itu, pendidik yang akan mengajar pasti memiliki dan menguasai bahan pelajaran yang akan disampaikannya pada peserta didik. Demikian pula halnya dengan materi atau bahan ajar berupa kitab klasik merupakan unsur inti yang ada di dalam kegiatan pengajian kitab kuning, karena memang kitab itulah yang diupayakan untuk dikuasai oleh mahasiswa.

Pengajian kitab kuning pada mahasiswa di Ma'had Al-Birr Unismuh meliputi kajian-kajian kitab kuning (buku-buku referensi klasik) intensif, seperti kitāb Fiqih al-Sunnah, kitāb al-Raḥīq al-Makhtūm, kitāb al-Arba'īn al-Nawāwiyah, kitab Qawā'id al-Lugah dan Kitāb Subul al-salām. Kajian-kajian kitab yang diadakan tiap pekan tersebut dipandu secara khusus oleh ustadz yang merupakan dosendosen Ma'had Al-Birr alumni Perguruan Tinggi Timur Tengah, seperti Arab Saudi, Pakistan, Sudan dan lain sebagainya.

c. Input Harapan-harapan

Input harapan-harapan adalah berupa: visi, misi, tujuan, dan sasaransasaran yang ingin dicapai oleh sebuah lembaga pendidikan. Tujuan adalah unsur 
penting untuk suatu kegiatan, maka dalam kegiatan apapun tujuan tidak bisa diabaikan. Maka tujuan dari pelaksanaan pengajian kitab kuning memiliki fungsi sebagai pengikat aktivitas antara pengasuh pengajian dengan mahasiwa Ma'had Al-Birr. Oleh sebab itu, merumuskan tujuan merupakan langkah pertama yang dilakukan oleh pihak pimpinan Ma'had Al-Birr dalam merancang kegiatan pengajian kitab kuning.

Adapun tujuan-tujuan pelaksanaan pengajian kitab kuning pada mahasiswa di Ma’had Al-Birr memiliki 3 (tiga) tujuan jangka pendek, yaitu:

a. Pengetahuan (al-fahm), dimana mahasiswa dapat mengetahui dan memahami setiap materi yang berkaitan kitab yang diajarkan.

b. Pelaksanaan (al-tatbīq), dimana mahasiswa mampu melaksanakan dan mengajarkan apa yang ia ketahui di dalam kehidupannya.

c. Pembiasaan (al-ta'wīd), dimana mahasiswa mampu membiasakan apa yang telah ia pelajari melalui kitab kuning untuk dilaksanakan di dalam kehidupan sehari-harinya selama di Ma'had hingga menjadi suatu kebutuhan yang tidak bisa ia tinggalkan setelah kembali ke daerahnya masing-masing.

Adapun tujuan jangka panjang dari pelaksanaan pengajian kitab kuning di Ma'had Al-Birr adalah; dalam rangka mencetak kader-kader ulama muda yang siap diterjunkan ke tengah-tengah masyarakat sebagai muballigh atau da'i.

\section{Proses Pelaksanaan Pengajian Kitab Kuning di Ma'had Al-Birr}

Dalam perspektif pendidikan, proses merupakan berubahnya sesuatu menjadi sesuatu yang lain. Proses adalah suatu pelaksanaan atau kejadian yang terjadi secara alami atau didesain dengan sengaja. ${ }^{13}$ Berdasarkan penjelasan di atas, maka proses dapat dijelaskan sebagai pendekatan, metode dan strategi.

Dalam kegiatan pengajian kitab kuning di Ma'had Al-Birr Unismuh, pengasuh pengajian menggunakan metode yang relatif sama, yaitu metode halaqah

\footnotetext{
13 E. Mulyasa, Kurikulum berbasis kompetensi : konsep, karakteristik, dan implementasi (Bandung: PT Remaja Rosdakarya, 2002), 22.
} 
karena karakter kitab kuning yang diajarkan memang sangat identik antara satu kitab dengan yang lain.

Salah satu keistimewaan dari metode halaqah ialah mahasiswa diminta tertebih dahulu mempelajari sendiri materi-materi yang akan diajarkan oleh gurunya, sehingga mereka dapat menyelaraskan pemahamannya dangan pemahaman gurunya tentang maksud dari teks yang ada dalam sebuah kitab. Sistem ini mendidik para mahasiswa belajar secara mandiri. ${ }^{14}$ Dengan demikian, hasil pelajaran lebih tahan lama dan membekas dalam ingatan mereka.

Pada pengajian kitab kuning dengan menggunakan metode halaqah, umumnya pengasuh atau ustadz di awal pertemuan memilih beberapa mahasiswa untuk membaca materi, jika ustadz mendengarkan ada yang keliru pada bacaan mahasiswa maka ia segera menegur. Metode tuntunan ini tampaknya cocok dipraktekkan di Ma'had Al-Birr karena mahasiswa sudah memiliki dasar-dasar bahasa Arab yang cukup untuk membaca kitab kuning.

Selanjutnya, metode pembelajaran kitab yang di gunakan Ma'had Al-Birr adalah qira'ah-terjemah. Pada penerapan metode qiraah-terjemah ini, setelah mahasiswa membacakan kitab sesuai kemampuan mereka, pengajar membaca kembali keseluruhan teks yang akan dibahas, selanjutnya memberi terjemahan kata per kata sesuai makna kontes bacaan, dan mahasiswa mencatat terjemahan tersebut di atas atau di samping teks dengan pulpen/pensil.

Bahkan sebagian mahasiswa ada yang menyiapkan catatan khusus untuk menulis kosakata dari kitab yang mereka pelajari. Pada saat menerjemahkan bacaan kitab kuning, sebagian dari pengajar biasanya bertanya balik kepada mahasiswa mengenai arti mufradat atau kosakata asing yang terdapat dalam bacaan. mengenal perawi, penjelasan kosa kata, penjelasan kalimat, hadist secara global, faedah hadist, kesimpulan .

Metode penyampaian materi lainnya yang dipergunakan dalam pengajian adalah metode ceramah, dimana ustads duduk di depan mahasiswa menjelaskan

\footnotetext{
14 Cindra Nurdi, "METODE PEMBELAJARAN TAHFIZH AL-QUR'AN (Studi Komparasi Pada Pondok Tahfizh Hamalatul Qur'an Bantul Dan Pondok Tahfizhul Qur'an SahabatQu Depok Sleman),” 2018.
} 
tema tersebut selama 50 (lima puluh) menit, setelah itu para mahasiswa diberikan kesempatan untuk bertanya langsung kepada ustads yang berkaitan dengan tema tersebut atau permasalah-permasalahan yang terjadi ditengah masyarakat yang ada hubungannya dengan tema tersebut.

Dengan demikian, pengkajian kitab yang berbahasa Arab, dengan penerapan metode tuntunan dan qiraah-terjemah membuat mahasiswa tidak hanya terlatih dalam menerjemahkan naskah-naskah bahasa Arab, tetapi juga dalam membaca teks bahasa Arab dengan menerapkan pengetahuan ilmu bahasanya, yaitu: nahwu dan sharaf.

\section{Output pada Pengajian Kitab Kuning di Ma'had Al-Birr}

Output adalah hasil langsung dan segera dari sebuah proses pendidikan. ${ }^{15}$ Selain istilah output, dikenal pula istilah lain yakni outcome. Menurut, outcome adalah efek jangka panjang dari suatu proses pendidikan. Dengan demikian dapat dikatakan bahwa output adalah hasil yang dicapai dalam jangkan pendek, sedangkan outcome adalah hasil yang terjadi setelah pelaksanaan kegiatan jangka pendek. ${ }^{16}$

Output dari pengajian kitab kuning di Ma'had Al-Birr Unismuh mengacu kepada tujuan awal diselenggarakannya kegiatan pengajian, yaitu antara lain: a. AlFahm, mahasiswa memiliki pemahaman yang baik dan benar terhadap konten atau isi kitab kuning yang dipelajari, b. Al-Tatbīq, mahasiswa dapat mempraktekkan materi yang didapatkan dalam kegiatan pengajian dalam kehidupan sehari, khususnya selama berada di kampus, dan c. Al-Ta'wīd, mahasiswa sudah terinternalisasi sehingga dapat membiasakan diri melaksanakan setiap materi yang telah diajarkan tanpa menunggu instruksi atau perintah.

Adapun outcome atau luaran jangka panjang dari kegiatan pengajian kitab kuning di Ma'had Al-Birr adalah bahwa setelah mahasiswa menyelesaikan proses

\footnotetext{
15 Toto Suharto, "Konsep Dasar Pendidikan Berbasis Masyarakat," Cakrawala Pendidikan, no. 3 (2005): 3.

16 Muhammad Nurtanto, "Mengembangkan Kompetensi Profesionalisme Guru Dalam Menyiapkan Pembelajaran Yang Bermutu," 2016.
} 
pendidikannya (alumni) ia dapat berkiprah di tengah-tengah masyarakat untuk berdakwah dan menyampaikan pesan-pesan agama sebagaimana materi yang pernah dipelajari di kegiatan pengajian kitab kuning di Ma'had Al-Birr Unismuh.

Dalam usianya yang kini sudah memasuki tahun ke-20, Ma'had Al-Birr Unismuh Makassar sudah menghasilkan ratusan alumni yang tersebar di berbagai daerah. Sebahagian alumninya ada yang mengaktifkan dirinya dalam dunia dakwah dan pendidikan, dengan menjadi da'i atau guru agama di daerah asal mereka. Ma'had Al-Birr sendiri telah memberdayakan alumni-alumninya untuk menjadi da'i di daerah-daerah terpencil di kawasan Indonesia Timur. Menurut data tahun 2018 jumlah da'i yang tersebar adalah 248 orang, dengan sebaran sebagai berikut: Sulawesi 122 orang, Maluku 55 orang, dan Papua 71 orang. Sebagian lagi alumni melanjutkan pendidikan ke jenjang yang lebih tinggi.

\section{Kesimpulan}

Berdasarkan penjelasan sebelumnya dapat disimpulkan bahwa, sistem pengajian kitab kuning yang berlangsung di Ma'had Al-Birr Universitas Muhammadiyah Makassar; meliputi input, proses dan output. Input yang dimaksud antara lain adalah; input sumber daya, yaitu para mahasiswa dan dosen pengasuh, input perangkat lunak, yaitu tata tertib dan materi yang diajarkan, dan input harapan-harapan, yaitu tujuan dari pelaksanaan pengajian kitab kuning pada mahasiswa di Ma'had Al-Birr. Tujuannya antara lain untuk memberi pemahaman (al-fahm) teks kitab klasik kepada mahasiswa, mampu melaksanakan (al-tatbīq) apa yang mereka ketahui, serta dapat membiasakan diri (al-ta'wīd) dengan apa yang telah ia pelajari melalui kitab kuning untuk dilaksanakan di dalam kehidupan sehari-harinya.

Dalam proses pelaksanaan pengajian kitab kuning, para ustadz sebagai sumber menggunakan beberapa metode dan pendekatan tergantung karakter kitab, yakni; metode halaqah, ceramah dan qira'ah dan terjemah. Sedang materi kajian merujuk kepada lima kitab kuning yang berbeda, yakni; kitāb Fiqh-al- 
Sunnah, al-Raḥīq al-Makhtum, kitāb al-Arba'īn al-Nawāwiyah, kitāb Subul al-Salām dan kitāb Qawā'id al-Lugah.

Melalui kegiatan pengajian kitab kuning dihasilkan luaran (output) yang memiliki pemahaman yang baik, siap melaksanakan dan membiasakan diri dengan apa yang dipelajari. Para alumni yang telah memiliki penguasaan kitab kuning tersebut selanjutnya (outcome) menjadi kader-kader muballig atau da'i yang akan menegakkan amar makruf dan nahi mungkar di tengah-tengah masyarakat. 


\section{DAFTAR PUSTAKA}

Abdullah, Amin. Pengembangan Metode Studi Islam Dalam Perspektif Hermeneutika Sosial dan Budaya. Vol. 6, 2003.

Arikunto, Suharsimi. Manajemen Penelitian. Jakarta: Rineka Cipta, 2013.

Azra, Azyumardi. Pendidikan Islam : tradisi dan modernisasi menuju milenium baru. Jakarta: Logos Wacana Ilmu, 2002.

Dhofier, Zamakhsyari. The Pesantren Tradition: The Role of the Kyai in the Maintenance of Traditional Islam in Java. Tempe, Ariz.: Monograph Series Press, Program for Southeast Asian Studies, Arizona State University, 1999.

Kadir, Ahmad. Dasar-Dasar Metodologi Penelitian Kualitatif. Makassar: CV. Indobis Media Centre, 20013.

Moleong, S.J. Metodologi Penelitian Kualitatif. Bandung: Remaja Rosdakarya, 1991.

Mulyasa, E. Kurikulum berbasis kompetensi: konsep, karakteristik, dan implementasi. Bandung: PT Remaja Rosdakarya, 2002.

Nurdi, Cindra. “METODE PEMBELAJARAN TAHFIZH AL-QUR'AN (Studi Komparasi Pada Pondok Tahfizh Hamalatul Qur'an Bantul Dan Pondok Tahfizhul Qur'an SahabatQu Depok Sleman)," 2018.

Nurtanto, Muhammad. "Mengembangkan Kompetensi Profesionalisme Guru Dalam Menyiapkan Pembelajaran Yang Bermutu," 2016.

Rahim. Kendali Mutu Pendidikan Agama Islam. Jakarta: Departemen Agarna RI, 2001.

Sugiyono. Metode Penelitian Kuantitatif Kualitatif Dan R\&D. Bandung: Alfabeta, 2008.

Suharto, Toto. "Konsep Dasar Pendidikan Berbasis Masyarakat." Cakrawala Pendidikan, no. 3 (2005).

Wahid, Marzuki. Pesantren Masa Depan: Wacana Pemberdayaan Dan Transformasi Pesantren. Jakarta: Pustaka Hidayah, 1999.

Wartini, Atik. "Corak Penafsiran M. Quraish Shihab Dalam Tafsir Al-Misbah." Hunafa: Jurnal Studia Islamika 11, no. 1 (2014): 109-26. 